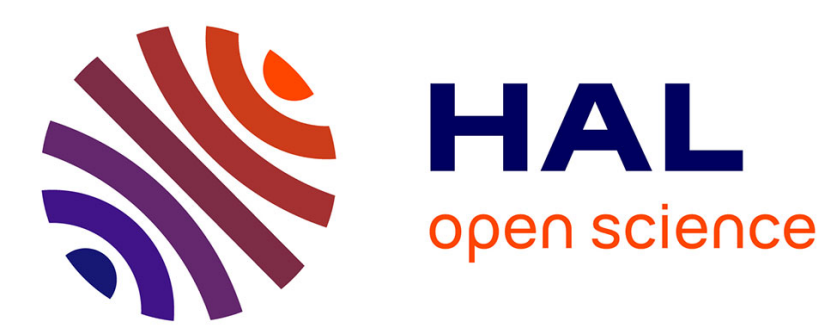

\title{
TEMPERATURE DEPENDENCE OF THE SPACE-CHARGE-REGION WIDTH OF A Ti-nGaAs SCHOTTKY DIODE EBIC STUDY
}

\author{
B. Sieber, P. Carton
}

\section{> To cite this version:}

B. Sieber, P. Carton. TEMPERATURE DEPENDENCE OF THE SPACE-CHARGE-REGION WIDTH OF A Ti-nGaAs SCHOTTKY DIODE EBIC STUDY. Journal de Physique IV Proceedings, 1991, 01 (C6), pp.C6-223-C6-224. 10.1051/jp4:1991634 . jpa-00250720

HAL Id: jpa-00250720

https://hal.science/jpa-00250720

Submitted on 1 Jan 1991

HAL is a multi-disciplinary open access archive for the deposit and dissemination of scientific research documents, whether they are published or not. The documents may come from teaching and research institutions in France or abroad, or from public or private research centers.
L'archive ouverte pluridisciplinaire HAL, est destinée au dépôt et à la diffusion de documents scientifiques de niveau recherche, publiés ou non, émanant des établissements d'enseignement et de recherche français ou étrangers, des laboratoires publics ou privés. 


\section{TEMPERATURE DEPENDENCE OF THE SPACE-CHARGE-REGION WIDTH OF A Ti-nGaAs} SCHOTTKY DIODE EBIC STUDY

\section{B. SIEBER and P. CARTON}

Laboratoire de Structure et Propriétés de l'Etat Solide, URA 234, Bâtiment C6, Université des Sciences et Techniques de Lille Flandres-Artois, F-59655 Villeneuve d'Ascq Cedex, France

The EBIC mode of the SEM is currently used for the determination of semiconductors parameters such as the diffusion length $\mathrm{L}$ and the doping level $\mathrm{N}_{\mathrm{d}}$. For that purpose, the configuration where a Schottky diode is perpendicular to the electron beam offers the advantage that it allows the determination of both $\mathrm{L}$ and $\mathrm{N}_{\mathrm{d}}$ as well as the detection of their fluctuations in the material located underneath the diode. The technique simply requires to record the charge collection efficiency $\eta_{c c}$ as a function of beam voltage $E_{O}$.

We have performed such experiments at $300 \mathrm{~K}$ and $77 \mathrm{~K}$ on a bulk siliçon doped GaAs specimen $\left(\mathrm{n} \approx 6.10^{16} \mathrm{~cm}^{-3}\right.$ ) with a low diffusion length $(<1 \mu \mathrm{m})$.

We show that the determination $\mathrm{N}_{\mathrm{d}}$ does depend on the analytical form of the generation function introduced in the calculations. The experimental curves are well-fitted with the generation function derived by Akamatsu et al [1] and by assuming recombination in the space charge region (SCR). This recombination could be due to the presence of a deep level.

From the decrease of $\mathrm{L}$ with temperature, which is area dependent, it is suggested that $L$ is controlled by deep levels at $300 \mathrm{~K}$ and by shallow levels at $77 \mathrm{~K}$.

More interesting is the non similarity of the shapes of the $300 \mathrm{~K}$ and $77 \mathrm{~K} \eta_{\mathrm{cc}}=\mathrm{f}\left(\mathrm{E}_{\mathrm{O}}\right)$ curves: when the experiments are made at $77 \mathrm{~K}$ by decreasing $E_{0}$, and only in that case, a deviation of the curve in the 7 $10 \mathrm{kV}$ range is observed (figure 1). 


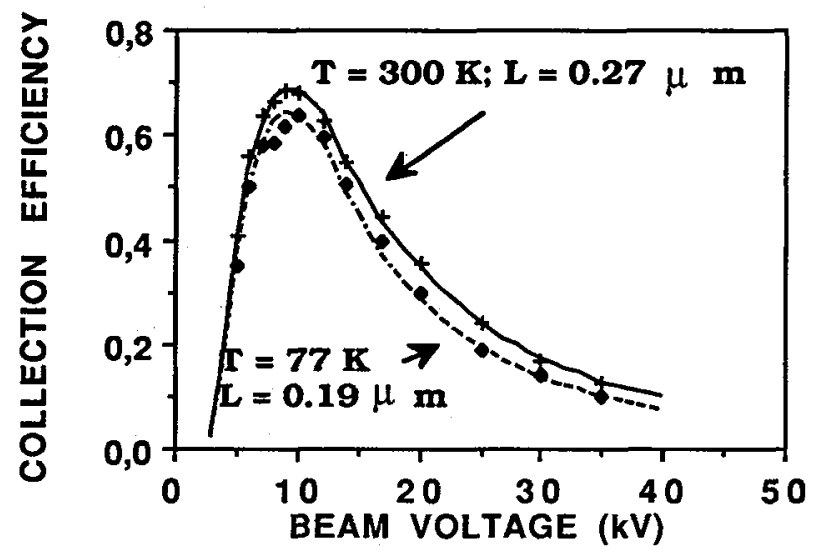

Figure 1: Energy dependent experimental charge collection efficiency curves at $+300 \mathrm{~K}$ and $77 \mathrm{~K}$. The last curve has been recorded by decreasing the accelerating voltage The best fits are obtained for the sets of parameters: $\mathrm{T}=300 \mathrm{~K}: \mathrm{L}=0.27 \mu \mathrm{m}, \mathrm{N}_{\mathrm{d}}=6.10^{16} \mathrm{~cm}^{-3}, \mathrm{EC}=0.86$ $\mathrm{T}=77 \mathrm{~K}: \mathrm{L}=0.19 \mu \mathrm{m}, \mathrm{N}_{\mathrm{d}}=5.10^{16} \mathrm{~cm}^{-3}, \mathrm{EC}=0.80$. The $77 \mathrm{~K}$ curve recorded by increasing the beam voltage is given by $\ldots \ldots$.

Futhermore, the maximum of the collection efficiency is shifted by 1 $2 \mathrm{kV}$ towards high $\mathrm{E}_{\mathrm{o}}$ values in comparison with that obtained at $300 \mathrm{~K}$. These observations lead us to suggest that the deviation cannot be the result of a static situation, but that it is correlated to a change of the physical situation of the specimen when excited at high voltage. Therefore, we propose that, during the experiment from high to low $\mathrm{E}_{\mathrm{O}}$, there is a change in the ionisation state, in the SCR, of a double deep level. Such a change could be produced by an hole and photon flux from the diffusive region.

[1] B. Akamatsu, P. Henoc and R. Benetton-Martins, J. Microsc. Spectrosc. Electron., 14, (1989) 